\title{
AlEKSANDRA GAWRYSIAK-ZABŁOCKA
}

\author{
Uniwersytet Kardynała Stefana Wyszyńskiego
}

\section{NOWE TECHNOLOGIE A OBOWIAZZEK UJAWNIANIA DOKUMENTÓW I INFORMACJI PRZEZ SPÓŁKI W ŚWIETLE DYREKTYWY 2003/58/WE}

\section{WSTĘP}

Ostatnie kilkadziesiąt lat to okres niewiarygodnego wręcz postępu technicznego. To co naszym dziadkom czy nawet ojcom wydawało się niemożliwe i o czym pisali nieśmiało jedynie co bardziej odważni wizjonerzy ${ }^{1}$, jest teraz elementem codziennego życia. Nowe technologie w dziedzinie informacji i komunikacji wywierają wpływ na wiele aspektów naszego życia. W szczególności funkcjonowanie podmiotów gospodarczych ulega głębokim przemianom. Jasne jest w związku z tym, że nie wszystkie zasady ustalone w epoce przedkomputerowej „są adekwatne na początku XXI wieku”. Dlatego też konieczna stała się analiza przepisów prawa w celu dokonania w nim odpowiednich zmian.

W artykule przedstawiona zostanie geneza i postanowienia Dyrektywy Parlamentu Europejskiego i Rady 2003/58/WE z dnia 15 lipca 2003 r. zmieniającej Dyrektywę Rady 68/151/EWG w zakresie wymagań dotyczących jawności w odniesieniu do niektórych typów

' Por. na przykład V. Bush, As We May Think, "The Atlantic Monthly" 176.1 (1945), s. 101-108; M. GreEnBERger, The Computers of Tomorrow, «The Atlantic Monthly» 213.5 (1964), s. 63-67. 
spółek $^{2}$ - aktu, który jest próbą dostosowania europejskiego prawa wspólnotowego do sytuacji, jaka powstała w skutek rozwoju nowoczesnych technologii i stworzonych przez nie możliwości (dalej akt ten w skrócie nazywany jest dyrektywą 2003/58/WE lub po prostu Dyrektywą Nowelizującą). Jednocześnie postaram się wskazać na konieczność nowelizacji polskich przepisów w tym zakresie.

II. DLACZEGo NIEZBĘDNE STAEY SIĘ ZMIANY W REGULACJI WSPÓLNOTOWEJ ODNOSZĄCEJ SIĘ DO OBOWIĄZKU UJAWNIANIA DOKUMENTÓW I INFORMACJI PRZEZ SPÓŁKI: GENEZA DYREKTYWY 2003/58/WE

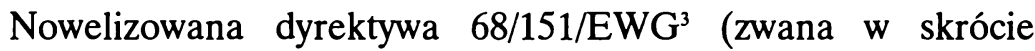
Pierwszą Dyrektywą - dlatego, iż była to pierwsza dyrektywa przyjęta w dziedzinie prawa spólek ${ }^{4}$ ) pochodzi z 1968 r. i ma na celu harmonizację prawa państw członkowskich dotyczącego ogłaszania podstawowych dokumentów i informacji niektórych typów spółek (spółek akcyjnych, spółek z ograniczoną odpowiedzialnością i spółek komandytowo-akcyjnych), ważności ich zobowiązań oraz możliwości unieważnienia spółki. Powstawała ona w czasie, gdy zupełnie naturalną i jedyną do pomyślenia formą zgłaszania wniosków do organu rejestrującego (poza ustnym zgłoszeniem wniosku do protokołu), prowadzenia rejestru i uzyskiwania $\mathrm{z}$ niego informacji była forma pisemna. Obecnie jednak znacznie ła-

${ }^{2}$ O.J. 2003, L 221, s. 13-16.

${ }^{3}$ Dyrektywa Rady Wspólnot Europejskich z 9 marca 1968 zmierzająca do zharmonizowania gwarancji, jakie są wymagane w państwach czlonkowskich od spółek, w znaczeniu artykułu 58 akapit 2 Traktatu, dla ochrony interesów zarówno wspólników, jak i osób trzecich (68/151/EWG), O.J. 1968, L 65, s. 8-12.

4 Wraz z innymi dyrektywami w dziedzinie prawa spólek została wydana na podstawie art. 54 ust. 3 lit. g Traktatu o ustanowieniu EWG (obecnie art. 44 ust. 2 lit g TWE). Pełna lista dyrektyw z zakresu prawa spółek: http://europa.eu.int/eur-lex/en/lif/reg/en_register_1710.html. 
twiej i szybciej można zawiadomić o zaistniałych zmianach przy użyciu na przykład poczty elektronicznej czy stron internetowych. Na początku XXI wieku jest też coraz większe dążenie, by informacje o podmiotach prowadzących działalność gospodarczą były udostępniane zainteresowanym nie tylko $\mathrm{w}$ formie papierowej, ale także $w$ formie elektronicznej.

Ponadto w latach 60-tych XX wieku dokumenty pochodzące od spółek mogły mieć jedynie formę papierową. Za słuszne uznano wówczas, by umieszczane były na nich pewne informacje o spótkach. Dopiero później rozwój techniki umożliwił spółkom posiadanie stron internetowych czy porozumiewanie się ze światem drogą elektroniczną. W związku $z$ tym niezbędne są regulacje dotyczące umieszczania tych informacji na dokumentach elektronicznych.

Oczywiście pewną część problemów, pojawiających się w związku z rozwojem techniki, można rozwiązać przy dokonywaniu odpowiedniej wykładni (najczęściej będzie to wykładnia celowościowa) już obowiązujących przepisów. Na przykład można wnioskować, że te informacje, które muszą być podawane przez spółki w wychodzących od spółek tradycyjnych pismach, powinny być przez te spółki uwidaczniane także w pismach, które mają postać inną niż papierowa, czy też być zamieszczane na stronach WWW. Jednakże zdarzają się sytuacje, gdy rozumowania podobnego do powyższego nie będzie można zastosować $\mathrm{z}$ równą łatwością.

Niektóre państwa członkowskie podjęły więc pewne kroki stworzenia ram prawnych dla wykorzystania dostępnych technologii przy publikacji informacji przez spółki. Przykładem mogą być Niemcy, w których obowiązuje ustawa o elektronicznym rejestrze i kosztach sądowych telekomunikacjis. Dane zapisane w rejestrze

\footnotetext{
${ }^{5}$ Ustawa z dnia 10 grudnia 2001 r. - Gesetz über elektronische Register und Justizkosten für Telekommunikation (ERJuKoG), BGBl I, s. 3422. Co do szczególowego opisu stanu prawnego obowiązującego w Niemczech por. O. ScHOLZ, Die Einführung elektronischer Handelregister im Europarecht, «Europäische Zeitschrift für Wirtschaftsrecht» 15.6 (2004), s. 174-175.
} 
udostępniane są w Internecie także w Wielkiej Brytanii, Francji i Austrii ${ }^{6}$. Różny jest jednak zakres takich regulacji.

W celu ujednolicenia prawa obowiązującego na obszarze państw członkowskich Wspólnoty Europejskiej, konieczne stało się rozwiązanie wymienionych wyżej zagadnień na szczeblu prawa wspólnotowego. Dlatego też w czerwcu 2002 r. Komisja przedstawiła projekt nowelizacji Pierwszej Dyrektywy', który po uwzględnieniu opinii Komitetu Społeczno-Ekonomicznego ${ }^{8}$ i pierwszym czytaniu w Parlamencie Europejskim w dniu 12 marca 2003 r., został ostatecznie przyjęty przez Radę 15 lipca 2003 r. Państwa członkowskie są zobowiązane do implementacji dyrektywy 2003/58/WE do 31 grudnia $2006 \mathrm{r}$.

\section{POSTANOWIENIA DYREKTYWY 2003/58/WE}

W preambule dyrektywy 2003/58/WE podkreślono między inny$\mathrm{mi}, \dot{z e}$ jej celem jest $\mathrm{z}$ jednej strony sprawić, by informacje dotyczące spółek były łatwiej i szybciej dostępne dla zainteresowanych, $\mathrm{z}$ drugiej zaś znacznie ułatwić spółkom wywiązywanie się z nałożonych na nie obowiązków ogłoszeniowych.

Dyrektywa 2003/58/WE w niektórych wypadkach dopuszcza, w innych zaś nakazuje dokonywanie określonych czynności „w formie elektronicznej"'. W związku z tym, że w języku potocznym pojęcie to ma wiele znaczeń, fundamentalny charakter ma zawarta w Dyrektywie definicja tego zwrotu. Dla celów nowelizowanego art. 3 Pierwszej Dyrektywy „w formie elektronicznej” oznaczać ma, że informacja jest początkowo wysłana i otrzymana w miejscu przeznaczenia przy pomocy urządzeń elektronicznych służących do

${ }^{6}$ Por. K. OPLUSTIL, P. WIÓREK, Aktualne tendencje w europejskim prawie spótek - nowe akty prawa wspólnotowego, «PPH» 13.4 (2004), s. 16.

'O.J. 2002, C 227 E, s. 377.

${ }^{8}$ O.J. 2003, C 85, s. 13.

${ }^{9}$ Ang. by electronic means, niem. in elektronischer Form, fr. par voie électronique. 
przetwarzania (włączając w to cyfrową kompresję) i przechowywania danych, i całkowicie nadana, przeniesiona i otrzymana w sposób określony przez państwa członkowskie przy pomocy kabla, radia, środków optycznych lub innych środków elektromagnetycznych ${ }^{10}$.

Postanowienia Dyrektywy Nowelizującej dotyczą w pierwszym rzędzie tego, w jaki sposób zainteresowane podmioty mogą zgłaszać do organu rejestrowego wnioski o wpis lub dołączenie do akt rejestrowych. Nakłada ona na państwa członkowskie obowiązek zapewnienia, że od 1 stycznia 2007 r. przesyłanie przez spółki oraz inne podmioty obowiązane do dokonywania zgłoszeń jakichkolwiek dokumentów i informacji (które muszą być ogłoszone zgodnie z postanowieniami Pierwszej Dyrektywy ${ }^{11}$ ) będzie również możliwe w formie elektronicznej. Oznacza to, że wy bó r for my zgłoszenia (tradycyjnej lub elektronicznej) ma co do zasady należeć do podmiotu składającego wniosek. Dyrektywa przewidziała jednak wyjątek: państwa członkowskie

${ }^{10}$ Por. art. 3 ust. 8 znowelizowanej Pierwszej Dyrektywy.

"Por. art. 2 Pierwszej Dyrektywy, zgodnie z którym państwa członkowskie mają zapewnić obowiązkową jawność w odniesieniu do spólek w stosunku do m.in. następujących dokumentów i informacji: aktu założycielskiego oraz statutu i ich zmian; kompletnego tekstu zmienionego aktu założycielskiego lub statutu w jego aktualnym brzmieniu po każdej zmianie aktu założycielskiego lub statutu; powołania, zakończenia sprawowania funkcji, jak też danych osób, które, jako organ przewidziany w prawie albo członkowie takiego organu są upoważnieni do reprezentowania spółki wobec osób trzecich oraz do reprezentowania jej w postępowaniu sądowym lub uczestniczą w zarządzaniu, nadzorowaniu lub kontrolowaniu spółki; co najmniej raz w roku kwoty kapitału subskrybowanego, jeśli akt założycielski lub statut wymieniają kapitał statutowy, chyba że jakiekolwiek podwyższenie kapitału subskrybowanego wymaga zmiany statutu; bilansu oraz rachunku zysków i strat za każdy rok gospodarczy; każdej zmiany siedziby spółki; likwidacji spółki; orzeczenia sądu o nieważności spółki; powolania likwidatorów, danych ich dotyczących oraz ich odpowiednich uprawnień, chyba że uprawnienia te wynikają w sposób wyraźny i wyłączny z przepisów prawa lub przepisów statutowych; zakończenia postępowania likwidacyjnego i wykreślenia $\mathrm{z}$ rejestru w państwach członkowskich, w których powoduje to skutki prawne. 
mogą nałożyć na wszystkie (albo pewne kategorie) spółki obowiązek zgłaszania po 1 stycznia 2007 r. w formie elektronicznej wszystkich (albo pewnych rodzajów) dokumentów i informacji.

Po drugie, Dyrektywa Nowelizująca porusza kwestię s posobu przechowywania akt rejestrowych. Wszystkie wskazane dokumenty i informacje, które są zgłaszane po 1 stycznia 2007 r., niezależnie od tego, czy na papierze, czy w formie elektronicznej, są przechowywane $w$ aktach rejestrowych albo wpisane do rejestru w postaci elektronicznej. W tym celu państwa członkowskie muszą zapewnić, by te dokumenty i informacje, które są zgłaszane po 1 stycznia 2007 r., były przetworzone w rejestrze na formę elektroniczną. Dokumenty i informacje zgłoszone na papierze do 31 grudnia 2006 r. nie muszą być automatycznie przetwarzane w rejestrze na formę elektroniczną. Państwa członkowskie muszą jednak zapewnić, że zostaną one w rejestrze przetworzone na formę elektroniczną na wniosek osoby zainteresowanej.

Po trzecie, Dyrektywa Nowelizująca określa w jaki sposób będzie można uzyskać informacje z rejestru. Odpis pełny lub częściowy każdego dokumentu lub informacji podlegających rejestracji na mocy tej dyrektywy musi być dostępny na wniosek, który od 1 stycznia 2007 r. może być złożony do rejestru na papierze albo w formie elektronicznej, według wyboru wnioskodawcy. Ponadto, od 1 stycznia 2007 r. odpisy muszą być dostępne $\mathrm{z}$ rejestru w postaci papierowej albo w formie elektronicznej, według wyboru wnioskodawcy, niezależnie od tego, czy dokumenty albo informacje zostały zarejestrowane przed czy po 1 stycznia 2007 r. Państwa członkowskie mogą jednakże zadecydować, że wszystkie - albo pewne rodzaje - dokumentów lub informacji, które zostały zarejestrowane na papierze do 31 grudnia 2006 r., nie będą dostępne $\mathrm{z}$ rejestru $\mathrm{w}$ formie elektronicznej, jeżeli pomiędzy zarejestrowaniem a złożeniem wniosku do rejestru upłynął ustalony okres. Okres ten nie może być krótszy niż 10 lat. Opłata zarówno za otrzymanie odpisu na papierze, jak i w formie elektronicznej, nie powinna przekraczać kosztów administracyjnych. Różnica 
pomiędzy odpisami na papierze, a tymi w formie elektronicznej będzie dotyczyć jednak uwierzytelnienia: odpisy na papierze powinny być poświadczone jako odpisy uwierzytelnione, chyba że wnioskodawca zrezygnuje $\mathrm{z}$ uwierzytelnienia, podczas gdy odpisy elektroniczne nie powinny być poświadczane jako uwierzytelnione, chyba że wnioskodawca wyraźnie tego zażąda ${ }^{12}$. Państwa członkowskie mają przy tym przyjąc środki konieczne dla zapewnienia, by uwierzytelnienie odpisów elektronicznych gwarantowało zarówno autentyczność ich pochodzenia, jak i spójność ich zawartości, za pomocą bezpiecznego podpisu elektronicznego w znaczeniu artykułu 2 ust. 2 Dyrektywy Parlamentu Europejskiego i Rady 1999/93/EEC z 13 grudnia 1999 r. w sprawie wspólnotowych ram w zakresie podpisów elektronicznych.

Po czwarte, Dyrektywa Nowelizująca określa też w nowy sposób zasady publikacji informacji w dzienniku o zasięgu ogólnokrajowym. Wyznaczony do tego celu dziennik będzie mógł być prowadzony w formie elektronicznej. Co więcej, państwo członkowskie może zadecydować o zastąpieniu ogłoszenia w wyznaczonym dzienniku o zasięgu ogólnokrajowym przez środek równie skuteczny, który powinien przynajmniej wiązać się $\mathrm{z}$ użyciem systemu umożliwiającego dostęp poprzez centralną platformę elektroniczną do ogłoszonych informacji w kolejności chronologicznej.

Po piąte, Dyrektywa Nowelizująca nakłada obowiązek podawania przez spółki informacji niezbędnych dla zidentyfikowania rejestru, w którym ich akta rejestrowe są przechowywane oraz numeru wpisu do rejestru, formy prawnej spółki, jej siedziby rejestrowej, ewentualnie informacji o stanie likwidacji, w pismach i zamówieniach handlowych niezależnie od tego, czy są one w formie papierowej czy zostały dokonane przy użyciu innego medium lub na stronach internetowych spółek.

\footnotetext{
${ }^{12}$ Poza ramami tego artykułu pozostaje kwestia, dlaczego nastąpiło zróżnicowanie w tym względzie odpisów i czy jest ono uzasadnione.
} 


\section{KONIECZNOŚĆ DOKONANIA ZMIAN W PRAWIE POLSKIM}

Z jednej strony zmieniająca się rzeczywistość, w której coraz większą rolę odgrywają środki elektroniczne, $\mathrm{z}$ drugiej zaś strony fakt, że została przyjęta nowa dyrektywa Wspólnoty Europejskiej, a na Polsce ciązy obowiązek dostosowania prawa krajowego do tych regulacji, powodują, że w niedługim czasie trzeba będzie podjąć kroki ku nowelizacji polskich przepisów traktujących o zasadach ogłaszania informacji przez spółki. Materia ta jest regulowana obecnie przez kodeks spółek handlowych ${ }^{13}$ i ustawę o Krajowym Rejestrze Sądowym $^{14}$ (oraz akty wykonawcze wydane na jej podstawie ${ }^{15}$ ).

W związku z powyższym polski prawodawca będzie musiał podjąć szereg decyzji.

$\mathrm{Na}$ początek trzeba będzie dookreślić co w prawie polskim znaczy zwrot „w formie elektronicznej”. Z Dyrektywy Nowelizującej wynika bowiem, że to państwa członkowskie mają określić sposób przekazywania w formie elektronicznej informacji i warunki, jakim muszą odpowiadać przekazywane w ten sposób informacje. Trzeba będzie zastanowić się, jak zapewnić, aby wypełnianie np. elektronicznych formularzy było $z$ jednej strony jak najprostsze dla użytkownika, a $z$ drugiej strony dawało gwarancję, że dane zostały wprowadzone przez upoważnioną osobę i że nie doszło do jakichś błędów w czasie ich transmisji. Dobrze, aby w tej mierze zostały uwzględnione pozytywne i negatywne doświadczenia $\mathrm{z}$ funkcjonującego już od pewnego czasu w Polsce obowiązkowego przekazywania do Zakładu Ubezpieczeń Społecznych poprzez teletransmisję danych w formie dokumentu elektronicznego $\mathrm{z}$ aktualnego programu informatycznego udostępnionego przez ZUS

${ }^{13}$ Ustawa z dnia 15 września 2000 r. - Kodeks spólek handlowych (Dz.U. Nr 94, poz. 1037 ze zm.), dalej ksh.

${ }^{14}$ Ustawa z dnia 20 sierpnia 1997 r. o Krajowym Rejestrze Sądowym (Dz.U. z 2001 r. Nr 17, poz. 209 ze zm.).

${ }^{15}$ Por. przede wszystkim Rozporządzenie Ministra Sprawiedliwości z dnia 21 grudnia 2000 r. w sprawie szczególowego sposobu prowadzenia rejestrów wchodzących w skład Krajowego Rejestru Sądowego oraz szczególowej treści wpisów w tych rejestrach (Dz.U. Nr 117, poz. 1237 ze zm.). 
(tzw. Program Płatnik) ${ }^{16}$. Oprócz tego, przy opracowywaniu odpowiedniej regulacji należało by także skorzystać $\mathrm{z}$ pomysłów wcielonych w życie w innych państwach (niekoniecznie członków Wspólnoty Europejskiej), gdzie już od wielu lat dopuszcza się, czy nawet nakazuje, zgłaszanie danych w wersji elektronicznej. Chociaż Dyrektywa Nowelizująca nie nakłada takiego obowiązku, wydaje się, że niezbędne będzie wprowadzenie wymogu, aby wniosek $w$ formie elektronicznej był opatrzony bezpiecznym podpisem elektronicznym weryfikowanym przy pomocy ważnego kwalifikowanego certyfikatu.

Po drugie, trzeba będzie się zastanowić, czy Polska skorzysta z możliwości nałożenia na wszystkie (albo pewne kategorie) spółek obowiązku zgłaszania w formie elektronicznej wszystkich (albo pewnych rodzajów) dokumentów i informacji od 1 stycznia 2007 r.

Po trzecie, w prawie polskim powinno znaleźć się także uregulowanie dotyczące tego, w jaki sposób sprostać nałożonemu na państwa członkowskie obowiązkowi zapewnienia, by wszystkie dokumenty i informacje, które są zgłaszane po 1 stycznia 2007 r., były przetworzone w rejestrze na formę elektroniczną oraz w jaki sposób dokumenty i informacje zgłoszone na papierze do 31 grudnia 2006 r. mają być w rejestrze przetwarzane na formę elektroniczną na wniosek osoby zainteresowanej.

Ponadto trzeba będzie określić, w jaki sposób zainteresowani będą mogli składać wnioski o odpisy w formie elektronicznej oraz w jaki sposób (jeśli będzie takie życzenie wnioskodawcy) odpisy w formie elektronicznej będą wydawane. Zgodnie z postanowieniami Dyrektywy Nowelizującej, opłata za otrzymanie odpisu zarówno na papierze, jak i w formie elektronicznej, nie powinna przekraczać kosztów administracyjnych. W związku z tym nie da się uniknąć odpowiedzi

${ }^{16}$ Por. art. 47a ustawy z dnia 13 października 1998 r. o systemie ubezpieczeń spolecznych (Dz.U. Nr 137, poz. 887 ze zm.) oraz wydane na jego podstawie rozporządzenie Ministra Pracy i Polityki Spolecznej z dnia 3 lipca 2001 r. w sprawie warunków, jakie muszą spełnić płatnicy składek przekazujący dokumenty ubezpieczeniowe $w$ formie dokumentu elektronicznego poprzez teletransmisję danych (Dz.U. Nr 73, poz. 774 ze zm.). 
na pytanie, czy opłata za wydanie odpisu w formie elektronicznej ma być zawsze równa opłacie za wydanie odpisu na papierze, czy też może niższa lub wyższa w zależności od okoliczności konkretnego przypadku (np. od tego, czy dane są już dostępne w formie elektronicznej, czy też odpis w formie elektronicznej wydawany jest w drodze poczty elektronicznej czy na nośniku CD). Odpisy w formie elektronicznej mają, co do zasady, nie być poświadczane jako uwierzytelnione. Wyjątek stanowi sytuacja, gdy wnioskodawca wyraźnie tego zażąda. Wówczas trzeba zapewnić, by uwierzytelnienie odpisów elektronicznych gwarantowało zarówno autentyczność ich pochodzenia, jak i spójność ich zawartości, za pomocą bezpiecznego podpisu elektronicznego w znaczeniu artykułu 2 ust. 2 Dyrektywy Parlamentu Europejskiego i Rady 1999/93/EEC z 13 grudnia 1999 r. w sprawie wspólnotowych ram w zakresie podpisów elektronicznych - $\mathrm{i}$ taka regulacja będzie musiała znaleźć się w prawie polskim.

Polski ustawodawca będzie musiał także podjąć decyzję, czy Monitor Sądowy i Gospodarczy, w którym publikowane są ogłoszenia pochodzące od spólek, ma być nadal tradycyjną gazetą $\mathrm{w}$ formie papierowej (i wówczas nie będzie potrzeby zmian obowiązujących przepisów ${ }^{17}$ ), czy może ma być prowadzony w formie elektronicznej (trzeba, by w tym wypadku określić w jaki sposób) albo - idąc jeszcze dalej - ogłaszanie w nim danych ma być zastąpione „środkiem równie skutecznym, który powinien przynajmniej wiązać się z użyciem systemu umożliwiającego dostęp poprzez centralną platformę elektroniczną do ogłoszonych informacji w kolejności chronologicznej" (tu nowa regulacja musiałaby być bardzo obszerna).

Zajdzie także konieczność nowelizacji przepisów ksh, które mówią o tym, jakie informacje muszą podawać spółki na pismach od nich pochodzących ${ }^{18}$, poprzez doprecyzowanie/dopisanie, że infor-

17 Zasady wydawania Monitora Sądowego i Gospodarczego są regulowane ustawą z dnia 22 grudnia 1995 r. o wydawaniu Monitora Sądowego i Gospodarczego (Dz.U. z 1996 r. Nr 6, poz. 42 ze zm.).

${ }^{18}$ Por. art. 206 ksh i 374 ksh. Zupełnie odmienną kwestią jest, że przepisy te w swym obecnym brzmieniu nie są zgodne z Pierwszą Dyrektywą, bowiem dopusz- 
macje te powinny być umieszczane w pismach i zamówieniach handlowych niezależnie od tego, czy są one w formie papierowej, czy zostały dokonane przy użyciu innego medium i na stronach internetowych spółek. Ta część implementacji dyrektywy powinna być stosunkowo najprostsza.

Trzeba będzie także zadecydować, czy rozmaite przepisy wprowadzone do prawa polskiego w związku z implementacją dyrektywy 2003/58/WE będą miały zastosowanie jedynie do tych spólek, których dotyczy ta dyrektywa (tj. spółek akcyjnych, spółek z o.o. i spólek komandytowo-akcyjnych), czy też już z inicjatywy polskiego ustawodawcy będzie się je stosować do innych podmiotów (i tu pytanie, jak szeroko to rozumieć: spółek prawa handlowego, podmiotów wpisywanych do rejestru przedsiębiorców czy do wszystkich podmiotów wpisywanych do któregokolwiek rejestru prowadzonego w ramach KRS-u).

Last but not least - implementacja postanowień dyrektywy 2003/58/WE będzie się nieuchronnie wiązała z koniecznością opracowania odpowiednich programów, gwarantujących sprawne i bezbłędne przekazywanie, przetwarzanie i publikowanie danych. To zaś pociągnie za sobą realne koszty i wydatki, które będą musiały zostać uwzględnione w budżecie państwa.

\section{New TeChnologies and the Obligation to Disclose Documents AND PARTICULARS BY COMPANIES IN THE LIGHT OF DiRECTIVE 2003/58/WE}

\section{Summary}

Modern information and communication technology has a profound impact on our society. In particular, they have changed the way in which companies are functioning: the possible form of legal acts and of disclosure

czają nieznany tej dyrektywie wyjątek: nie ma zgodnie $\mathrm{z}$ ksh obowiązku podawania danych w pismach i zamówieniach handlowych spółki kierowanych do osób pozostających ze spółką w stałych stosunkach gospodarczych. 
and filing of company information. So-called First Company Law Directive adopted in 1968 included provisions on a compulsory disclosure of documents and particulars. Since in the beginning of 21 st century the compulsory disclosure system organised by the First Directive has become out-dated, the European Parliament and of the Council adopted Directive 2003/58/EC amending Council Directive 68/151/EEC, as regards disclosure requirements in respect of certain types of companies. In the article the provisions of the Directive 2003/58/EC are presented. Moreover, the author analyses what changes in the Polish Law will be necessary. 